and the determination of the local weather and climate appropriate to each crop. It is proposed to employ two agricultural meteorologists and subordinate staff for a preliminary period of five years, at an annual cost of Rs.40,000. The necessary grant has been made by the Imperial Council of Agricultural Research.

\section{The Musk Rat in Europe}

Two exhibition cases have recently been placed in the Central Hall at the Natural History Museum, South Kensington, immediately facing the visitor on entering the building, in order to inform the public what kind of animal the musk rat, Ondatra zibethica, Linn., is, how it lives, and the damage it does. Better known as musquash, the musk rat has been for many years of considerable commercial value because of its fur, which is very beautiful, being thick, soft, richly coloured, and glossy. Naturally an inhabitant of North America, it has been imported to Europe by misguided people who thought some advantage and profit might result from this step. The experiment provides yet another illustration of the serious danger involved in interference with the balance of Nature. In its original home, the musk rat's increase is controlled by the usual kind of checks, which do not exist or have not developed elsewhere. It is said that in 1905 two males and five females were turned loose in Bohemia; twenty-one years later, in 1926 , there were computed to be no fewer than a hundred millions of these animals in Central Europe. Owing to their burrowing habits, the damage that they do to waterways is enormous, and great expense has to be incurred in checking them. In Great Britain the danger has been recognised, and under the Destructive Imported Animals Act, 1932, regulations, which come into force on May 1, have been formulated to control the distribution of the musk rat in this country.

\section{Destruction of Rats}

Is addition to the British Museum pamphlet on rats, noticed in NaTuRE for Dec. 19, 1931, p. 1036 , two others have recently appeared. All deal with the specific characters and the natural history of the black and the brown rat, and with the methods of destroying rats or preventing their ingress, so that there is a considerable amount of overlapping; but each pamphlet has its own particular points of excellence. The Ministry of Agriculture and Fisheries Bulletin, No. 30 (price 6d. net), repeats in new and much more attractive form the old Miscellaneous Publication on rats, and its object is to supply practical information leading to rat-destruction. The second pamphlet, by Colin Matheson, deals with "The Brown and the Black Rat in Wales " (National Museum of Wales, price 6d. net), and discusses some very interesting facts bearing upon the occurrence of rats and the rat menace in the Principality. It is surprising to learn that in the years 1922-28 inclusive the rat-catcher in the Port Sanitary Area of Cardiff destroyed of black rats, by far the more rare of the two species in Britain at the present day,
22,036 from ships and 3072 from dock warehouses; and of the brown rat, only 50 and 266 in these areas respectively. But the proportions change as the docks recede, for in Cardiff City, from March 1928 until February 1930 , only 78 black rats were caught, as against 1961 brown rats. The menace of such great numbers of the plague-distributing black rat in the Port area is one which the author does well to emphasise.

\section{Implements from the Oldoway Beds}

Four original implements and casts of eleven others from the Oldoway beds in Tanganyika have been presented to the British Museum by Dr. L. S. B. Leakey on behalf of the East African Archæological Expedition, and are to be exhibited without delay at the top of the main staircase in the prehistoric section of the Department of British and Mediæval Antiquities. They come from the following beds, beginning at the base: Bed No. 1, associated with Deinotherium, a predecessor of the elephant and generally assigned to the Miocene: pre-Chelles types. Bed No. 2, lower part, with Hipparion and Elephas antiquus: early Chelles types. Bed No. 2, upper part, the horizon of Prof. Reck's Oldoway man, with Hipparion, Elephas antiquus, and Hippopotamusgorgops: late Chelles types. Bed No. 3, with fauna as Bed No. 2 : transition Chelles to St. Acheul. Bed No. 4, lower part, with Elephas antiquus, Hipparion, Hippopotamus gorgops, Pelorovis and extinct antelopes: early St. Acheul types. Bed No. 4, upper part, with same fauna as lower : advanced St. Acheul types.

\section{Japanese Plants in the Netherlands}

THE Leyden Branch of the Royal Horticultural Society of the Netherlands, in order to commemorate the founding of the well-known acclimatisation garden for Japanese plants by Dr. P. F. von Siebold, is planning to hold an exhibition, on May 4-8, at Leyden, of living Japanese plants, shrubs, and trees, many of which are descendants of plants imported by von Siebold. Belgian and Dutch horticulturists are collaborating to make this collection as complete as possible. At various other institutes of the University of Leyden, smaller exhibits will be held of the ethnographical, zoological, and botanical material gathered by von Siebold. Biographical materials will be shown in the University Print Collection. In the University gardens, which still contain more than forty of von Siebold's trees and shrubs, a bronze statue, by the sculptor, $\mathrm{O}$. Wenckebach, will be unveiled by the grandson of von Siebold and by the grandson of his head-gardener.

\section{Von Siebold and the "Flora Japonica"}

Philipp Franz von Siebold was born at Würzburg on Feb. 17, 1796. He studied at his home university, where he received his doctorate in medicine in 1820. In 1823 he arrived at Decima, Japan, as a military doctor, but he also devoted himself to the natural history, medicine, ethnology, ethnography, and history of Japan. At Nagasaki he founded a medical school and clinic, but for political reasons some of his ever-increasing botanical, zoological, 
mineralogical, and geological collections were confiscated by the Japanese authorities in 1828 ; fortunately, not long before he had sent many specimens to Leyden. He also sent a living tea plant to Java, thus originating tea culture on that island. In 1827, Siebold published a small catalogue of Japanese economic plants. On Dec. 30, 1829, political unrest was so acute that he was ordered to leave Japan, and he then settled in Holland. He met the German singer, J. J. Hoffmann, who was also a linguist. In 1845, Hoffmann published a description of Siebold's books, manuscripts, and maps which he had brought from Japan. Zuccarini, the Munich botanist, helped with the classification of botanical material. Publication of the "Flora Japonica " was begun in 1835 and continued until 1842, but after Zuccarini's death, von Siebold discontinued further publication and the materials became the property of the Government Herbarium at Leyden, where the Von Siebold Collection is still visited and consulted by botanists. Von Siebold's influence on horticulture was even greater. His imported specimens formed a nucleus for horticulture in Belgium and Holland, but the original "Jardin d'Acclimatisation: Nippon" no longer exists. His zoological collections are preserved in the Museum of Natural History at Leyden and his ethnographical material at the Leyden Ethnographical Museum. Von Siebold died at Munich on Oct. 18, 1866.

\section{Decline of Australian Parrakeets}

THE re-discovery of a species supposed to have become extinct is especially a matter of congratulation when it has some particular claim to interest, as is the case with the splendid grass-parrakeet (Neophema splendida), of which a pair has recently reached England as a present to H.M. The King. Mr. D. Seth-Smith, in commenting on this in the Avicultural Magazine for January (p. 36), mentions that a few captured specimens had appeared in Adelaide, and that, always rare, the species, which is found in south and south-western Australia, had completely disappeared for about sixty years, and was supposed to be extinct, until a specimen occurred at Koonibha, crippled by collision with a wire fence. The special interest of the species lies in the very brilliant colouring of the male, which has a blue face and wing-patches, a scarlet breast, and yellow abdomen, contrasting with the green of the upper surface; the female has no red and is generally duller. The length is about eight inches. A whole group of small grass-seed-eating Australian parrakeets like this appears to be on the decline, common species like the turquoisine (N.pulchella) suffering as well as this rare one. Fortunately, like so many Australian birds, they are free breeders in captivity, and may possibly be preserved if domesticated as the budgerigar has been.

\section{False Mimicry in Animals}

THE short-tailed South American monkeys known as uakaris are never common in captivity, so it is as well to direct attention to the recent acquisition of a specimen of the red uakari (Cacajao rubicundus) by the Zoological Society of London, which exhibits it in the Tropical House along with some more familiar American monkeys. The resemblance of this species to an orang-utan in miniature is noticeable, and is paralleled in the Bird House next door by a specimen of the South American magpie tanager (Cissopis leveriana), which exhibits an equally striking resemblance in miniature to the magpie. Other more striking examples could be given, in both mammals and birds, of this false mimicry, or resemblance between creatures which do not inhabit the same region, when size as well as general appearance correspond. In the Bird House may also be seen an example of Chaulet's Cissa (Cissa hypoleuca Chauleti), which will be interesting to watch, as, like the better-known Indian species $(C$. sinensis $)$, this green bird changes into blue without a moult, the change taking place by a gradual alteration of tint, which reminds one of the fading into blue of green paint.

\section{A Direct Reading Optical Micrometer}

A Microscope for measuring small lengths has recently been put on the market by Messrs. W. Ottway and Co., Ltd., Orion Works, Ealing, W.5. The microscope, which gives a magnification of 25, is about $6.5 \mathrm{~cm}$. long and is mounted on a small tripod. Focusing is effected by sliding the microscope tube through the holder, fine adjustment being made by rotating a milled ring on the stand. Measurements are obtained by a direct reading of a scale on a graticule fitted into the microscope, a screw focusing adjustment being provided to bring the graticule into the focal plane of the eyepiece. Scales reading to 0.01 in. or 0.001 in. are supplied and are easily interchangeable. The instrument can conveniently be used as a linen counter, or for the measurement of Brinell impressions or of small objects up to $0 \cdot 1$ in. in length. For measurements of length up to $10 \mathrm{~mm}$. an alternative objective, fitted with a $0 \cdot 1 \mathrm{~mm}$. scale and giving a magnification of 15 , is obtainable. As the graticules may be ruled to any desired scale or pattern, the micrometer should prove useful as a test instrument in many industrial operations. It can easily be applied, for example, to the testing of screw threads, a graticule with the required thread form being used. Its compactness and the ease and speed with which readings may be made are additional advantages.

\section{Performance of Gears}

In a paper by Messrs. Hyde, Tomlinson, and Allan, of the National Physical Laboratory, read before the Institution of Automobile Engineers on April 4, an interesting account was given of researches which have been in progress at the Laboratory during the past few years on the performance of gears. The best gears are made of special alloy steels, either air or oil hardened, and afterwards finished to an accuracy of a few ten-thousandths of an inch by grinding. The work of the Laboratory shows that such gears can transmit power with the very high efficiency of more than 99 per cent. At the high speeds of rotation to which gears are subjected, a tooth out of its true position by less than a thousandth of an inch may come into mesh with a shock sufficient to double or

$$
\text { No. 3258, VoL. 129] }
$$

